\title{
Environmental Social Governance (ESG) Disclosure Score Rating of Bloomberg
}

\author{
$1^{\text {st }}$ Zaky Machmuddah \\ Accounting Department \\ Faculty of Economicss and Business \\ Universitas Dian Nuswantoro \\ Semarang, Indonesia \\ zaky.machmuddah@dsn.dinus.ac.id
}

\author{
$2^{\text {nd }}$ Ratna Wardhani \\ Accounting Department \\ Faculty of Economics and Business \\ Universitas Indonesia \\ Jakarta, Indonesia \\ ratnawardhani@yahoo.com
}

\begin{abstract}
The current paper will explain ESG disclosure score rating based on Bloomberg data of many countries in the world during 2014-2018. The rating is categorized into eight ratings, namely: the best country rating for corporate ESG performance, the best country rating for corporate environmental performance, the best country for corporate social performance, the best country rating for corporate governance performance, the worst country rating for corporate ESG performance, the worst country rating for corporate environmental performance, the worst country rating for corporate social performance and the worst country rating for corporate governance performance. Data of ESG, environmental, social, and governance disclosure score are derived from Bloomberg amounted 4.800 data. SPSS program is used to analysis the data. The research findings indicated that highest rating for corporate ESG performance was Sri Lanka. Sri Langka was also highest rating for corporate environmental and corporate social performance. Meanwhile for corporate governance performance rating, it belonged to Turkey. Bahrain was the lowest rating for corporate ESG, corporate social and corporate governance performance. For corporate environmental performance, Oman was the lowest. The descriptive result of the research is useful for motivating companies all over the world to continually increase their corporate ESG performance. Then, it will affect to their personal branding and company value.
\end{abstract}

\section{Keywords-ESG, disclosure, score, Bloomberg}

\section{INTRODUCTION}

Nowadays the issue of environmental damage is a very serious problem in the world. Therefore, along with the growth and development of companies in each country must be considered, because the impact of the company's operations on environmental damage is very large. One of the causes of environmental damage is the use of resources that are done in a way that is not suitable for large economic benefits. In addition, the company's production activities can also cause environmental pollution that will have an impact on social conflict.

The company must pay more attention to social and environmental responsibilities in order to gain legitimacy on the social role and environmental care that has been carried out by the company, so that the company will get the trust and support of the community. Trust and support gained from the community can have a good impact on the survival of the company in the future [1]. The application of corporate social responsibility programs can be developed using the triple bottom line concept introduced by [2], covering people, planet, and profit. All three are very important aspects to measure whether the company can be said to be successful through three criteria, namely: economic, environmental, and social.

Initiated this tripple bottom line concept when business people run company activities just for profit [2]. Company performance can not only be measured by the profits obtained by the company, but the success of a company is also measured by how much the company's contribution to environmental sustainability and the welfare of the surrounding community.

The company's environmental performance indicators are measured using an environmental disclosure score as seen from the company's operational activities and their impact on the environment, such as carbon emissions, greenhouse gas emissions, disclosure or measurement, reporting, climate change (risks caused by the company's operations), ecosystem changes, facilities that can cause environmental damage, business licensing, pollution, renewable energy, depletion of natural resources, waste disposal, the use of toxic chemicals, and others. The company's social performance in this study was measured using a social disclosure score as seen from several indicators, such as environmental welfare (in this case animals), child labor, discrimination, diversity (employee / board diversity), facilities that could pose social risks, wage problems employee work, political contributions and risks, sexual harassment, slavery, the selection of an advisory board on executive compensation, and others. While corporate governance in this study was measured using a governance disclosure score seen from several indicators, such as executive compensation, the relationship between corporate stakeholders (stakeholder), the rights of stakeholders (stakeholder), the division of positions, the authority of director, managers, shareholders and other parties [3].

Companies need to pay attention to the environmental conditions in which the company carries out its operational activities. If the company gets a good value on environmental aspects, the company's survival will also be good, because the company's survival will not only depend on improving the company's financial performance but also on the attention of all company stakeholders including the environment.

In addition to paying attention to environmental conditions, the company is also expected to contribute to the surrounding community, wherein conducting production activities are not only profit-oriented, but also pay attention to social issues and problems that occur, so that it can arouse 
the trust of all company stakeholders. This will have an impact on increasing personal branding and corporate value.

However, the company's attention does not only stop at environmental and social conditions, but also coupled with good corporate governance (GCG). GCG is one of the important aspects of improving economic efficiency, including a series of relationships between company management, the board of directors, shareholders, and stakeholders. By applying the principles of good corporate governance, the company will add value in the eyes of stakeholders. This is because good corporate governance can encourage the formation of clean, transparent and professional work patterns.

ESG reporting is a measure to achieve transparency about the performance of each company and a means of communication with stakeholders such as shareholders or investors [4], [5], employees, clients or the community. Therefore their reliability, consistency and relevance [6] are uncertain. Often they are created to communicate what the company wants [7], [8]. But reports are a useful tool for corporate and stakeholder reporting and are clearly an indicator of the importance of ESG issues in the company. Furthermore, frameworks such as GRI and third party verification contribute to the quality of reports [9], [10] and their transparency [11]. However, other research shows that reports issued to stakeholders in China still concentrate less on environmental reports and not on the economic consequences of CSR [12].

[13] found that companies and their managers reacted when assessed. A company with a low KLD rating will improve environmental performance to a higher level than high-ranking competitors. Every multinational corporation will spend a large amount of money on CSR activities. The annual report reports on this effort. Managers face pressure from various stakeholder groups to implement social responsibility [14]. The conclusion is that ESG reporting is an important tool to improve ESG performance of a company. It seems that companies that have published ESG reports in previous years 2011 are more likely to be members of the green company list than those who have not published reports. This is in line with [15] and [16] who see the ESG report as having a positive impact on the company's ESG performance.

ESG ratings are given by specialized ranking institutions that play an important role in the decision-making process of managers and investors who care about social responsibility and also for a lot of research. Some of the most important ESG ranking institutions include ASSET4 by Thomson Reuters, the Ethical Investment Research Service (EIRIS), Kinder Lydenberg Domini \& Co. (KLD) by MSCI, Sustainability Asset Management Group (SAM), and Bloomberg Sustainability. ESG ratings are used for a large number of empirical studies, which contribute importantly to the implications of managers and investors. More ESG ratings enable a more accurate analysis of the relationship between social and financial performance of the company.

[17] and [18] provide evidence of the fact that stocks with high ESG scores achieve excess returns, [19] and [20] conducted research that found results that there were no statistically significant differences in risk screening filtered against conventional portfolios. review in what ways the company's environmental efforts affect various aspects such as a company's market value or the cost of equity capital. They concluded that the stock market had no positive or negative effect on environmental actors. On the other hand, the results of, and suggest that company involvement in environmental issues, such as CSR, has a significant effect on reducing the cost of equity or debt. The results of the study show that the company's CSR activities in the controversial business sector indeed have a positive effect on market value. In terms of financial risk, found an insignificant relationship between CSP and systematic risk, while corporate social responsibility did not correlate positively with systematic risk measures for S\&P 500 companies.

This paper will explain the ESG score based on Bloomberg data from several countries in the world during 2014-2018. The ranking written is divided into eight, ranking the best countries in terms of ESG performance, ranking the best countries in terms of environmental performance, ranking the best countries in terms of social performance, ranking the best countries in terms of good corporate governance performance, ranking the worst countries in terms of ESG performance, ranking the worst country in terms of environmental performance, ranking the worst country in terms of social performance, ranking the worst country in terms of good corporate governance performance. The purpose of this paper is to motivate companies in all countries in the world to continue to improve the performance of ESG so that it will have an impact on personal branding and corporate value.

\section{LITERATURE REVIEW}

Signal theory is the basis of this research. This signal is in the form of information conveyed to stakeholders which impacts on the acquisition of feedback in the form of stakeholder recognition. By giving signals on the performance of ESG issued by the company, the company will get a response from the stakeholders. The response given by the stakeholders can increase the company's personal branding which will affect the company's survival.

Likewise, the legitimacy theory that explains about organizations or companies must pay attention to the values and norms set in the society where the organization is located in order to get legitimacy from the community. This is very important because the recognition from the community is a factor that affects the survival of the company. Organizations are part of the social system of society and try to create harmony between social values and the norms that exist in social life in society. With the harmony between the two systems, the company will get legitimacy from the community. However, there will be a threat to the legitimacy of the company if there is no harmony between the two systems.

In addition to signal theory and legitimacy theory, stakeholder theory is also related to this research. Stakeholder theory explains that there are parties who influence and are influenced so that the company carries out operational activities not only for its own sake, but must also contribute and be accountable to corporate stakeholders, including shareholders, creditors, consumers, suppliers, government, society, analysis, and other parties. Thus, companies need to get support from each stakeholder. [1] explain how important stakeholder support is to the survival of the company and that support must be sought through activities carried out by the company. The greater the strength of stakeholders, the greater the company's efforts to adapt. Social disclosure is considered as a form of company interaction with all stakeholders owned by the 
company. According to this theory explains the relationship between stakeholders and the information received.

\section{RESULT AND DISCUSSION}

Secondary data in the form of environmental, social, and governance data disclosure in the 2014-2018 Bloomberg period were used as the basis for analyzing this study. Descriptive analysis is used as a research method analysis tool. Based on data from Bloomberg for the period 20142018, 4,800 observations were obtained, consisting of 22 countries in the world. Of the 22 countries, Japan contributed 1,673 data, followed by Hong Kong with 731 data and Taiwan with 431 data. This proves that there are still many companies in the world who are not aware of the importance of reporting ESG performance.

Table 1 explains descriptive statistics, as many as 4,800 observational data were used in this study. The minimum value for ESG disclosure score is 7.62, for environmental disclosure score is 3.9, social disclosure score is 2.5 , and governance disclosure score is 3.42. While the maximum value for the ESG disclosure score of 95.24, for the environmental disclosure score of 98.95 , social disclosure score of 98.6, and governance disclosure score of 97.59. The mean of the ESG disclosure score of 50,101, for the environmental disclosure score of 53,2309, social disclosure score of 47.5119, and governance disclosure score of 49.6255 .

Seen in the data presented in table 2 shows that the average ESG score (67.16), the average Environmental score (78.71) and the highest average social score (70.85) obtained by the State of Sri Lanka. Sri Lanka is a developing country, however, in the ESG performance, reporting companies in the Sri Lankan country have not been required but are driven by an increasing commitment, companies registered in Sri Lanka to take a major step towards making sustainability reporting an effective practice and standard. This is because the support and regulation of the Sri Lankan government for companies in Sri Lanka is very strong. For the highest average governance score obtained by Turkey. Turkey is a developing country, however the implementation of corporate governance in Turkey shows that HPC Turkey is implementing superior corporate governance practices. As for the lowest average score of ESG performance, social performance and governance performance obtained by the state of Bahrain. However, the lowest average score for environmental performance was obtained by Oman.

TABLE I.

DESCRIPTIVE STATISTIC

\begin{tabular}{|c|c|c|c|c|c|c|c|}
\hline & $\boldsymbol{N}$ & Min & Max & Mean & Std. Deviation & Skewness & Kuortosis \\
\hline ESG & 4800 & 7.62 & 95.24 & 50.101 & 18.74458 & -0.1 & -0.913 \\
\hline ENV & 4800 & 3.9 & 98.95 & 53.2309 & 23.31007 & -0.107 & -1.06 \\
\hline SOC & 4800 & 2.5 & 98.6 & 47.5119 & 23.969 & -0.005 & -1.098 \\
\hline GOV & 4800 & 3.42 & 97.59 & 49.6255 & 21.05623 & -0.038 & -0.898 \\
\hline
\end{tabular}

a. Source of data Bloomberg, 2019

ESG, ENV, SOC, GOV Disclosure Score of Bloomberg

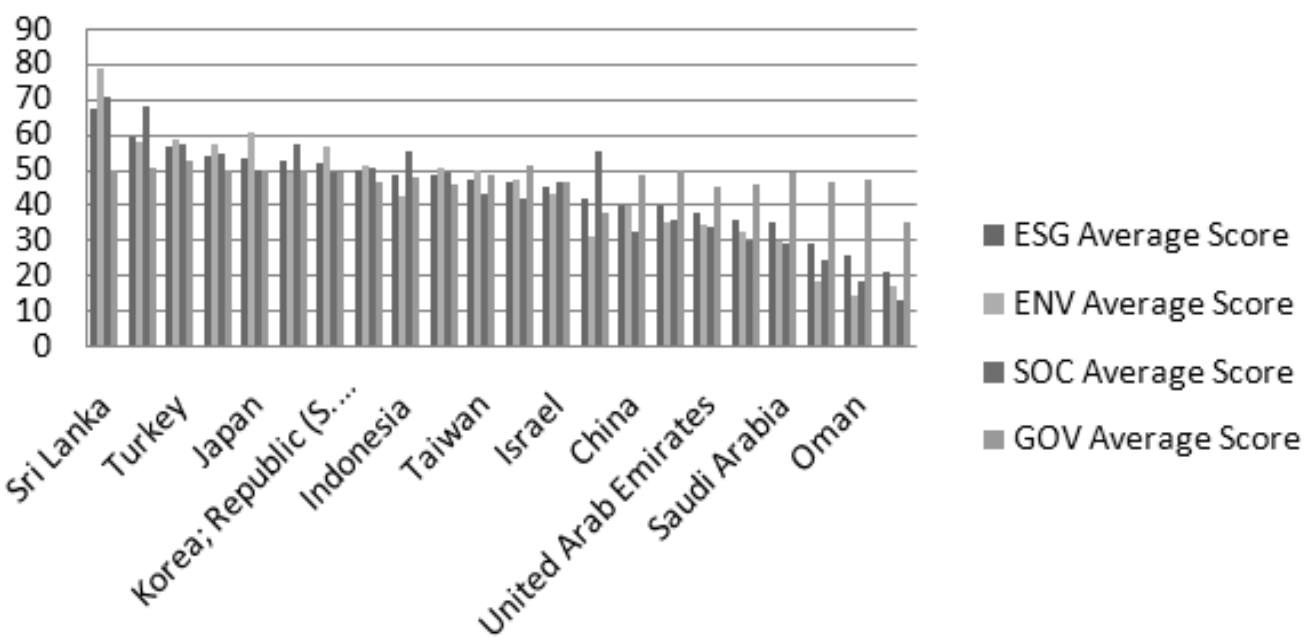

Fig. 1. Research Result

TABLE II. DESCRIPTIVE STATISTIC

\begin{tabular}{|c|c|r|r|r|r|r|}
\hline No. & Country & Sum of data & $\begin{array}{c}\text { ESG Average } \\
\text { Score }\end{array}$ & $\begin{array}{c}\text { ENV Average } \\
\text { Score }\end{array}$ & $\begin{array}{c}\text { SOC Average } \\
\text { Score }\end{array}$ & $\begin{array}{c}\text { GOV Average } \\
\text { Score }\end{array}$ \\
\hline 1 & Sri Lanka & 5.00 & 67.16 & 78.71 & 70.85 & 50.00 \\
\hline 2 & Thailand & 116.00 & 59.29 & 57.94 & 67.90 & 50.77 \\
\hline 3 & Turkey & 77.00 & 56.46 & 58.91 & 57.48 & 52.54 \\
\hline 4 & India & 353.00 & 54.12 & 57.55 & & 54.36 \\
\hline
\end{tabular}




\begin{tabular}{|c|c|c|c|c|c|c|}
\hline No. & Country & Sum of data & $\begin{array}{c}\text { ESG Average } \\
\text { Score }\end{array}$ & $\begin{array}{c}\text { ENV Average } \\
\text { Score }\end{array}$ & $\begin{array}{c}\text { SOC Average } \\
\text { Score }\end{array}$ & $\begin{array}{c}\text { GOV Average } \\
\text { Score }\end{array}$ \\
\hline 5 & Japan & $1,673.00$ & 53.64 & 60.67 & 49.92 & 50.14 \\
\hline 6 & Malaysia & 181.00 & 52.56 & 49.58 & 57.66 & 49.96 \\
\hline 7 & $\begin{array}{l}\text { Korea; Republic (S. } \\
\text { Korea) }\end{array}$ & 359.00 & 51.90 & 56.97 & 49.27 & 49.32 \\
\hline 8 & Philippines & 70.00 & 49.86 & 51.52 & 50.85 & 46.86 \\
\hline 9 & Indonesia & 123.00 & 48.86 & 42.88 & 55.55 & 47.74 \\
\hline 10 & Singapore & 154.00 & 48.78 & 50.44 & 49.56 & 46.01 \\
\hline 11 & Taiwan & 431.00 & 47.30 & 50.26 & 43.40 & 48.55 \\
\hline 12 & Hong Kong & 731.00 & 46.63 & 47.62 & 41.75 & 51.20 \\
\hline 13 & Israel & 38.00 & 45.47 & 43.11 & 46.88 & 46.46 \\
\hline 14 & Pakistan & 4.00 & 41.97 & 31.52 & 55.16 & 38.28 \\
\hline 15 & China & 349.00 & 40.16 & 40.17 & 33.00 & 48.48 \\
\hline 16 & Kazakhstan & 4.00 & 40.10 & 35.52 & 35.97 & 50.00 \\
\hline 17 & United Arab Emirates & 29.00 & 37.70 & 34.46 & 34.15 & 45.43 \\
\hline 18 & Kuwait & 27.00 & 35.75 & 32.93 & 29.68 & 45.97 \\
\hline 19 & Saudi Arabia & 28.00 & 35.58 & 29.88 & 29.23 & 49.32 \\
\hline 20 & Qatar & 31.00 & 29.09 & 18.50 & 24.39 & 46.37 \\
\hline 21 & Oman & 11.00 & 25.94 & 14.55 & 18.74 & 47.03 \\
\hline 22 & Bahrain & 6.00 & 21.38 & 17.15 & 13.46 & 35.31 \\
\hline & & $4,800.00$ & 67.16 & 78.71 & 70.85 & 52.54 \\
\hline
\end{tabular}

\section{CONCLUSION}

The conclusion from the results of this study is that the country with the highest average score for ESG performance is the country of Sri Lanka. Similarly, the highest average score for environmental performance and social performance. However, the highest average score for governance performance was obtained in Turkey. As for the lowest average score of ESG performance, social performance and governance performance obtained by the state of Bahrain. However, the lowest average score for environmental performance was obtained by Oman.

\section{ACKNOWLEDGMENT}

I would like to express my special thanks to my rector and also the chairperson of LPPM, who gave me the golden opportunity to do this wonderful project, which also helped me in doing a lot of research and I came to know about so many new things and I am really thankful to them.

\section{REFERENCES}

11 R. Gray, R. Kouhy, and S. Lavers, "Corporate Social and Environmental Reporting: A Review of The Literature and A Longitudinal Study of UK Disclosure," Accounting Auditing and Accountability Journal, vol. 8, no. 2, pp. 47-77, 1995.

[2] J. Elkington, "Accounting for The Tripple Bottom Line," Measuring Business Excellence, vol. 2, no. 3, pp. 18-22, 1998.
[3] Global Reporting Initiative, "G4 Sustainability Reporting Guidelines: Reporting Principles and Standard Disclosures," Amsterdam: GRI, 2013.

[4] J. C. Chan, and R. Welford, "Assessing Corporate Environmental Risk in China: An Evaluation of Reporting Activities of Hong Kong Listed Enterprises," Corporate Social Responsibility and Environmental Management, vol. 12, 2005, pp. 88-104, 2005.

[5] P. Ziek, "Making sense of CSR communication," Corporate Social Responsibility and Environmental Management, vol. 16, no. 3, pp. 137-145, 2009.

[6] A. Kolk, "Evaluating corporate environmental reporting," Business Strategy and the Environment, vol. 8, no. 4, pp. 225-237, 1999.

[7] J. Niskanen, and T. Nieminen, "The objectivity of corporate environmental reporting: a study of Finnish listed firms' environmental disclosures," Business Strategy and the Environment, vol. 10 , no. 1 , pp. $29-37,2001$

[8] C. Spence, "Social and environmental reporting and the corporate ego," Business Strategy and the Environment, vol. 18, no. 4, pp. 254265, 2009.

[9] A. Fonseca, "How credible are mining corporations' sustainability reports? A critical analysis of external assurance under the requirements of the international council on mining and metals," Corporate Social Responsibility and Environmental Management, vol. 17, no. 6, pp. 355-370, 2010.

[10] D. J. Lober, D. Bynum, E. Campbell, and M. Jacques, "The 100 plus corporate environmental report study: A survey of an evolving environmental management tool," Business Strategy and the Environment, vol. 6, no. 2, pp. 57-73, 1997.

[11] A. Kolk, and P. Perego, "Determinants of the adoption of sustainability assurance statements: an international investigation," Business Strategy and the Environment, vol. 19, no. 3, pp. 182-198, 2010 . 
[12] A. Kolk, P. Hong, and W. van Dolen, "Corporate social responsibility in china: an analysis of domestic and foreign retailers' sustainability Dimensions," Business Strategy and the Environment, vol. 19, no. 5, pp. 289-303, 2010.

[13] A. Chatterji, and M. Toffel, "How firms respond to being rated," Strategic Management Journal, vol. 31, no. 9, pp. 917-945, 2010.

[14] D. Crilly, M. Zollo, and M. Hansen, "Faking it or muddling through? Understanding decoupling in response to stakeholder pressures," Academy of Management Journal, vol. 55, no. 6, pp. 1429-1448, 2012.

[15] Y. Sumiani, Y. Haslinda, and G. Lehman, "Environmental reporting in a developing country: a case study on status and implementation in Malaysia," Journal of Cleaner Production, vol. 15, no. 10, pp. 895901, 2007.

[16] P. M. Clarkson, Y. Li, G. D. Richardson, and F. P. Vasvari, "Revisiting the relation between environmental performance and environmental disclosure: An empirical analysis," Accounting, Organizations and Society, vol. 33, no. 4-5, pp. 303-327, 2008.

[17] A. Kempf, and P. Osthoff, "The effect of socially responsible investing on portfolio performance," European Financial Management, vol. 13, no. 5, pp. 908-922, 2007.

[18] M. Statman, and D. Glushkov, "The wages of social responsibility," Financial Analysts Journal, vol. 65, no. 4, pp. 33-46, 2009.
[19] R. Galema, A. Plantinga, and B. Scholtens, "The stocks at stake: Return and risk in socially responsible investment," Journal of Banking \& Finance, vol. 32, no. 12, pp. 2646-2654, 2008.

[20] C. Mănescu, "Stock returns in relation to environmental, social and governance performance: Mispricing or compensation for risk?," Sustainable Development, vol. 19, no. 2, pp. 95-118, 2011. 